\title{
STUDY ON BODY FAT DENSITY PREDICTION BASED ON ANTHROPOMETRIC VARIABLES
}

\author{
Shiva Shanth Reddy Ainala, Nawaf Aljohani, Kaushik Roy, Xiaohong Yuan, and \\ Huiming A. Yu \\ Department of Computer Science, \\ North Carolina State A\&T University, Greensboro, USA
}

\begin{abstract}
For a human body to function properly it is essential to have a certain amount of body fat. Fat serves to manage body temperature, pads and protects the organs. Fat is the fundamental type of the body's vitality stockpiling. It is important to have a healthy amount of body fat. Overabundance of fat quotient can build danger of genuine wellbeing issues. Anthropometry is a broadly accessible and basic strategy for the appraisal of body composition. Anthropometry measures are weight, height, Body Mass Index (BMI), waist, boundary, biceps, skinfold etc. The human fat percentage is figured by taking anthropometric variables. We proposed a methodology to determine the body fat percentage using $R$ programming and regression formula. We analyzed 10 anthropometric variables and 3 demographic variables. Our study shows that the impact of certain variables has an edge over other in predicting body fat percentage.
\end{abstract}

\section{KEYWORDS}

Anthropometric variables, Body fat percentage, Fat prediction, Outliners using R programming.

\section{INTRODUCTION}

Fat is a manifestation of body tissue made out of cells which principally store lipids (unsaturated fats and related mixes). These cells are embedded in a framework of connective tissue [1]. There are two totally distinctive sorts of tissues: Brown Adipose Tissue (BAT) and White Adipose Tissue (WAT) [1]. Fat is an important component for body, which supplies energy making nutrients to function properly. Fat is source of essential fatty acids which are key dietary requirements and provide energy [2]. Fat protects body organs from stun, keeps up temperature of body and elevates solid cells to capacity [3]. Fat is imperative for generation of hormones in our body [4]. Fat is additionally structure as defensive pads for indispensable organs, for example, kidneys, heart and intestines [5]. Generally, if we look closely at the human body, there are certain number of fat cells which remain more or less constant throughout our adult lives. Therefore, we maintain an average ideal weight for the specific duration [1],[6].

Fat plays a vital role in our body mechanism. Specific measurements like anthropometric measurements have been used for assessment of body composition [7]. Anthropometric variable measurements such as Fat, Age, Height, Weight, Neck, Chest, Abdomen, Hip, Thigh, Knee, 
Ankle, Extended biceps, Forearm and Wrist are taken as an important qualities to analyze the body fat [8].

Anthropometry is a widely available and simple technique for the assessment of body composition which does not need specialized laboratory or expensive equipment [5]. Anthropometry variables produce precise appraisal of fat percentage [6]. Anthropometric measures are assessed for finding out the changes in individuals by valid methods [6], [9]. Various equations are generated to predict body fat percentage through anthropometric variables in [8], [3], [10]. Diverse set of comparisons uses people weight, stature and sex, which include smallest number of fat percentage predictions [11]. In fact, most of the previous methods measure body density which is then used to estimate body fat percentage.

Therefore, previous methods do not measure body fat directly. As a result of that, the body fat percentage depends on body's weight. However, each tissue in individual's boy has a different density. Addressing the above issue, in this research effort, regression models are designed and developed in an effort to predict the body fat percentage using 10 anthropometric variables which have precise values [8]. The proposed models suggest that inexpensive and simple anthropometry variables produces accurate estimate of percentage body fat [8], [3], [10]. This research study will be helpful to determine if body fat could be predicted from anthropometric and demographic variables. This study will also help identify how these variables are impacting on human body fat percentage.

\section{PROPOSED METHOD}

Body fat can be divided into two categories essential fat which is necessary for normal healthy functioning and storage fat which is the fat we accumulate beneath our skin, in certain specific areas inside our body and in muscles. Based on an extensive literature review, the research questions are developed. The experiments were conducted on a dataset that contains 4550 patient's data in an attempt to distinguish the effective anthropometric and demographic variables for assessing body fat based on the random sampling techniques [1]. The total sampling size is 4429. Data has been collected from "ROBA research Ltd" in India [8]. Different data analysis techniques were used including data cleaning, data validation, correlation, regression, stepwise regression, regression diagnostics. We adopted the best fit models for regression analysis.

The dependability and precision of estimation is compressed by connections in addition to t-tests and regression. Regression equations were cross validated using simple demographic and anthropometric measures. The equations were also utilized to estimate the fat rate. The basic expansion in the equations would be the age and gender. In view of the experimental goals, we proposed a general model with 10 anthropometric variables. Moreover, that model used demographic data to estimate body fat percentage by using two models. Model 1 with 3 variables and model 2 with all the variables. The body fat percentage measured through the proposed models will help us monitor our body fat. This research effort also finds the variables which are most effective in calculating body fat percentage. 


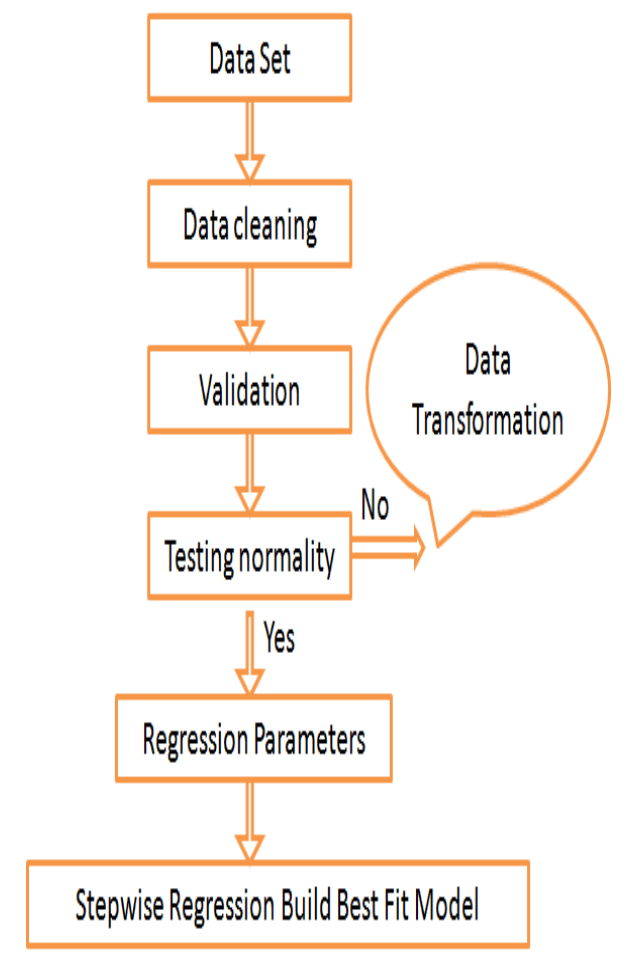

Fig.1 Block diagram of Research Methodology

\subsection{Data Analysis}

$\mathrm{R}$ programming and $\mathrm{R}$ Rattle were used to analyze the data. The experiments were conducted using Box plot and Histograms (for Normal distribution). Normality tests (Shapiro-wilk test) were carried out for data reduction. Correlation and Stepwise Regression analysis were deployed for estimating the 'Cause-and-Effecting' best fit model.

\subsection{Data Access \& Cleaning}

All the Lab report data used for our analysis is available in the electronic format. By using different techniques this data was converted into csv files. Total 4550 samples were converted into data table format. Data cleaning and validation process was performed using R programming Language.

\subsection{Data Validation}

We followed some inferential techniques for data normalization. The Box plot demonstrates the outliers and histogram data shows the normal distribution. Shapiro-Wilk test was performed for normality test.

The data used for analysis had more variation and deviations, and then data was normalized by performing various data cleaning and data validation techniques. From Fig.2, it is found that dark spots indicate a strong positive correlation between 0 to 1 while the lighter spots reveal weak positive correlation between 0 to -1 . 
International Journal of Data Mining \& Knowledge Management Process (IJDKP) Vol.5, No.3, May 2015

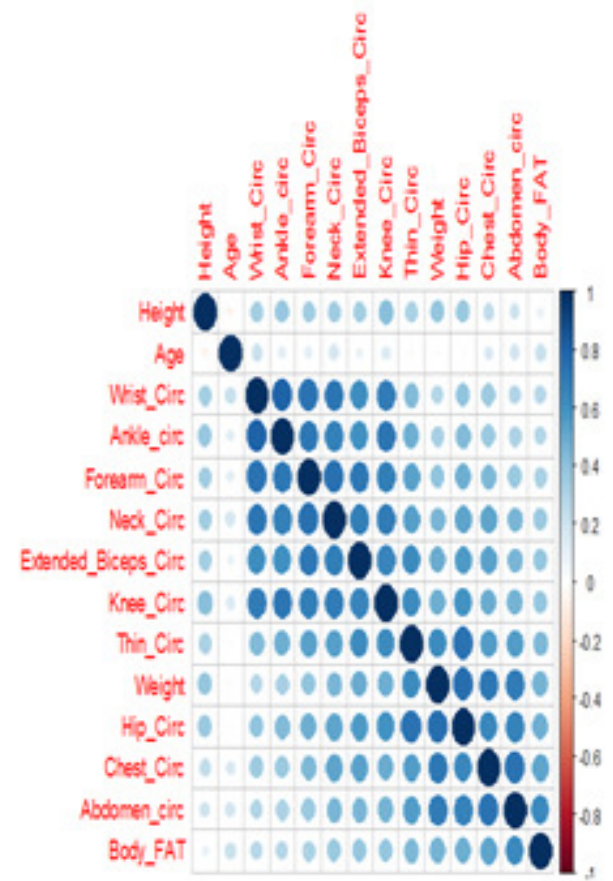

Fig.2 Data Correlation by Pearson Method
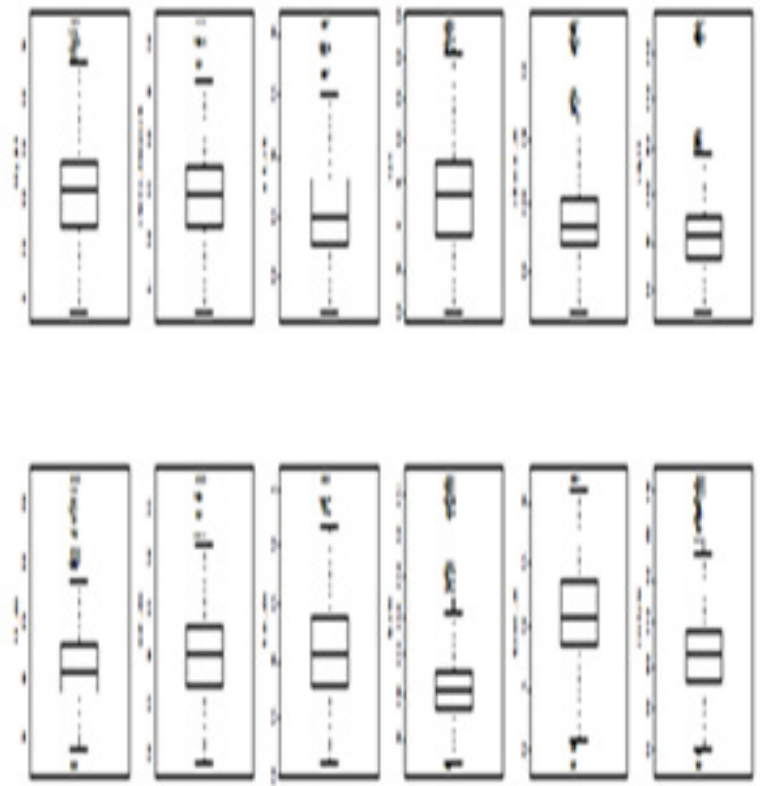

Fig. 3 Outliers identified using Boxplot 

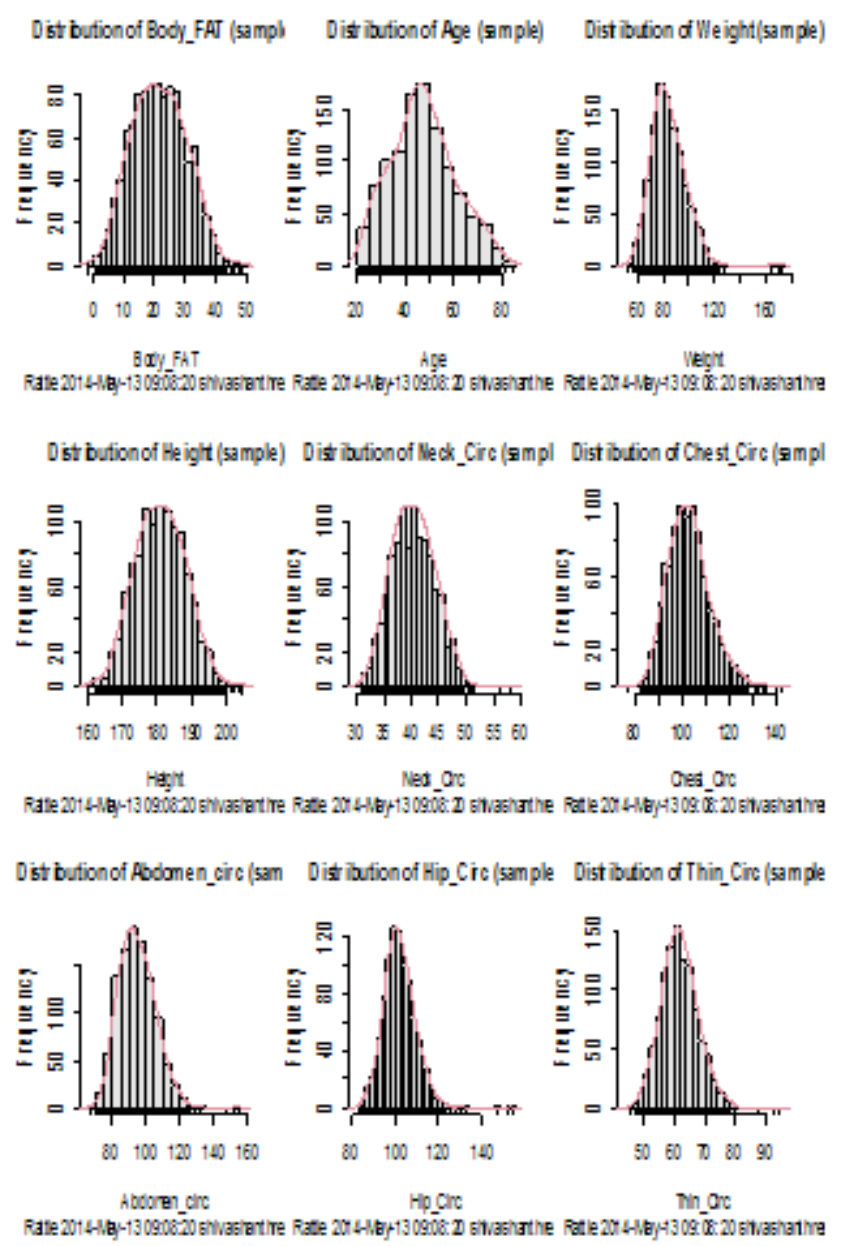

Fig.4 Normal distribution using Histograms

\section{RESULTS}

\subsection{Test of Normality}

From Figs. 3 and 4, we identified outliers for different anthropometry measures. These are Body Fat (), Age (), Height (), Weight (), Neck (), Chest (), Abdomen (), Hip (), Thigh (), Knee (), Ankle (), Extended biceps (), Forearm () and Wrist (). After removing outlier summarization, we present the mean values and standard deviations (stds) in Table 1 for different anthropometry measures.

\subsection{Regression Model-I Analysis}

From Table 2 we find that regression exploratory variables are $99 \%$ statistically significant. Summary of regression correlation with $\mathrm{R}=0.726, \mathrm{R}$ Square $=0.527$ and adjusted $\mathrm{R}$ Square $=$ 0.526 shows a moderate modelling for predicting body fat. Age and Weight variables positively predicted body fat. Height represents a negative predictor. Negative and positive exploration 
International Journal of Data Mining \& Knowledge Management Process (IJDKP) Vol.5, No.3, May 2015

variables are 99\% statistically significant. Equation (1) regression Diagnosis. The values with this equation closely predicts the fat percentage.

Body fat $=26.412+0.188 *$ Age $+0.543 *$ Weight $-0.327 *$ Height

(1)

\begin{tabular}{|c|c|c|c|c|c|}
\hline & & & \multicolumn{3}{|c|}{ Shapiro-Wilk } \\
\cline { 4 - 6 } variables & Mean & Std & Statistic & df & Sig. \\
\hline abdomen_circ & 94.07 & 9.721 & .994 & 1429 & .000 \\
\hline Age & 46.98 & 12.796 & .988 & 1429 & .000 \\
\hline ankle_circ & 25.20 & 3.214 & .992 & 1429 & .000 \\
\hline body_fat & 21.02 & 8.346 & .997 & 1429 & .003 \\
\hline chest_circ & 102.54 & 7.924 & .994 & 1429 & .000 \\
\hline extended_biceps & 34.38 & 4.041 & .992 & 1429 & .000 \\
\hline forearm_circ & 30.85 & 3.492 & .992 & 1429 & .000 \\
\hline Height & 180.81 & 7.076 & .995 & 1429 & .000 \\
\hline hip_circ & 101.63 & 6.462 & .997 & 1429 & .005 \\
\hline knee_circ & 40.73 & 3.617 & .991 & 1429 & .000 \\
\hline neck_circ & 40.10 & 3.640 & .980 & 1429 & .000 \\
\hline thin_circ & 61.39 & 5.412 & .996 & 1429 & .002 \\
\hline Weight & 82.69 & 11.678 & .992 & 1429 & .000 \\
\hline wrist_circ & 20.43 & 3.090 & .970 & 1429 & .000 \\
\hline
\end{tabular}

Table 1: SHAPIRO-WILK TEST FOR VARIABLES

\subsection{Regression Model-II Analysis}

From Table 3, we find that regression exploratory variables are 99\% statistically significant. Summary of regression correlation with $\mathrm{R}=0.843$, $\mathrm{R}$ Square $=0.71$ and adjusted $\mathrm{R}$ Square $=$ 0.708 represents a very strong modeling for predicting body fac. Neck circ, Chest circ and Hip circ variables negatively predict the body fat. Abdomen circumference, thigh circumference, forearm circumference and wrist circumference variables have positiove impacts on predicting the body fat. The other variables, including Knee circumference $(\mathrm{cm})$, Ankle circumference $(\mathrm{cm})$ and extended biceps circumference $(\mathrm{cm})$ are not statistically significant. Negative and positive exploration variables are $95 \%$ statistically significant in finding the body fat. Equation (2) is also proposed for regression Diagnosis. This model has more precise values as compared to equation (1).

Body FAT $=20.211-0.602 *$ Neck circumference $-0.215 *$ Chest circumference $+1.017 *$ Abdomen circumference $(\mathrm{cm})--0.417 *$ Hip circumference $+0.203^{*}$ Thigh circumference $+0.274 *$ Forearm circumference $+0.568 *$ Wrist circumference 
International Journal of Data Mining \& Knowledge Management Process (IJDKP) Vol.5, No.3, May 2015

\begin{tabular}{|c|c|c|c|c|c|c|c|c|}
\hline \multirow[t]{2}{*}{ Model-II } & \multicolumn{2}{|c|}{$\begin{array}{l}\text { Unstandardized } \\
\text { Coefficients }\end{array}$} & \multirow{2}{*}{$\begin{array}{c}\begin{array}{c}\text { Standardized } \\
\text { Coefficients }\end{array} \\
\text { Beta } \\
\end{array}$} & \multirow[t]{2}{*}{$\mathbf{t}$} & \multirow[t]{2}{*}{ Sig. } & \multirow[t]{2}{*}{$\mathbf{R}$} & \multirow{2}{*}{$\underset{\text { Square }}{\mathbf{R}}$} & \multirow{2}{*}{\begin{tabular}{|c} 
Adjusted \\
R \\
Square
\end{tabular}} \\
\hline & B & Std. Error & & & & & & \\
\hline (Constant) & -20.211 & 2.548 & & -7.931 & 0 & \multirow{11}{*}{$0.843^{\mathrm{a}}$} & \multirow{11}{*}{0.71} & \multirow{11}{*}{0.708} \\
\hline Neck circ & -0.602 & 0.099 & -0.263 & -6.062 & 0 & & & \\
\hline Chest circ & -0.215 & 0.04 & -0.204 & -5.436 & 0 & & & \\
\hline Abdomen circ & 1.017 & 0.033 & 1.185 & 30.432 & 0 & & & \\
\hline Hip circ & -0.417 & 0.057 & -0.323 & -7.259 & 0 & & & \\
\hline Thigh circ & 0.203 & 0.06 & 0.132 & 3.373 & 0.001 & & & \\
\hline Knee circ & -0.081 & 0.111 & -0.035 & -0.725 & 0.469 & & & \\
\hline Ankle circ & 0.015 & 0.133 & 0.006 & 0.113 & 0.91 & & & \\
\hline $\begin{array}{l}\text { Extended } \\
\text { biceps circ }\end{array}$ & 0.13 & 0.075 & 0.063 & 1.742 & 0.082 & & & \\
\hline Forearm circ & 0.274 & 0.094 & 0.115 & 2.913 & 0.004 & & & \\
\hline Wrist circ & 0.568 & 0.165 & 0.21 & 3.445 & 0.001 & & & \\
\hline
\end{tabular}

Table 2: SHAPIRO-WILK TEST FOR REGRESSION MODEL 1

\begin{tabular}{|c|c|c|c|c|c|c|c|c|}
\hline \multirow{2}{*}{ Model } & \multicolumn{2}{|c|}{$\begin{array}{c}\text { Unstandardized } \\
\text { Coefficients }\end{array}$} & $\begin{array}{c}\text { Standardized } \\
\text { Coefficients }\end{array}$ & \multirow{2}{*}{ T } & Sig. & R & $\begin{array}{c}\text { R } \\
\text { Square }\end{array}$ & $\begin{array}{c}\text { Adjusted R } \\
\text { Square }\end{array}$ \\
\cline { 2 - 6 } & $\mathbf{B}$ & $\begin{array}{c}\text { Std. } \\
\text { Error }\end{array}$ & Beta & & & & & \\
\hline (Constant) & $\begin{array}{c}26.41 \\
2\end{array}$ & 4.291 & & 6.155 & .000 & & & \\
\hline Age (yrs) & .188 & .012 & .288 & 15.594 & .000 & & \\
\hline $\begin{array}{c}\text { Weight } \\
\text { (kg) }\end{array}$ & .543 & .016 & .760 & 34.172 & .000 & $.726^{\mathrm{a}}$ & \multirow{2}{*}{.527} & .526 \\
\cline { 1 - 5 } $\begin{array}{c}\text { Height } \\
(\mathrm{cm})\end{array}$ & -.327 & .026 & -.277 & -12.376 & .000 & & & \\
\hline
\end{tabular}

Table 3: SHAPIRO-WILK TEST FOR REGRESSION MODEL 2

\section{CONCLUSION}

This research provides an insight of how body fat can increase the risk of having serious health issues such as high blood pressure, high cholesterol content, diabetes, cancer etc. Our results conclude that the body fat percentage depends on different factors, including age, weight, gender. All the anthropometric variables have their own impact while abdomen_circ, thigh_circ, forearm_circ and wrist_circ have signification impacts on predicting body fat percentage. In addition, this research also proposed regression models that can help predict the body fat percentage. Therefore, based on anthropometric variables, one can determine the ideal value of body fat percentage. The results we obtained provide a novel way of predicting body fat percentage using specific anthropometric values.

\section{REFERENCES}

[1] P. L. ouchard C, Leblanc C, Tremblay A, Thériault G, "Inheritance of the amount and distribution of human body fat," Int J Obes. 1988, vol. 12(3), pp. 205-215, 1988.

[2] Dollman, J., et al. (0000). "Dietary intake, physical activity and TV viewing as mediators of the association of socioeconomic status with body composition: a cross-sectional analysis of Australian youth." Int J Obes 31(1): 45-52. 
International Journal of Data Mining \& Knowledge Management Process (IJDKP) Vol.5, No.3, May 2015

[3] Jackson, A. S. and M. L. Pollock (1978). "Generalized equations for predicting body density of men." British journal of nutrition 40(03): 497-504.

[4] Folsom, A. R., et al. (1990). "Incidence of hypertension and stroke in relation to body fat distribution and other risk factors in older women." Stroke 21(5): 701-706.

[5] G. E. van der Ploeg, S. M. Gunn, R. T. Withers, and A. C. Modra, "Use of anthropometric variables to predict relative body fat determined by a four-compartment body composition model," Eur J Clin Nutr, vol. 57, pp. 1009-1016, //print 0000.

[6] C. Pongchaiyakul, Kosulwat, V., Rojroongwasinkul, N., Charoenkiatkul, S., Thepsuthammarat, K., Laopaiboon, M., Nguyen, T. V. and Rajatanavin, R, "Prediction of Percentage Body Fat in Rural Thai Population Using Simple Anthropometric Measurements," Obesity Research, vol. 13, pp.729-738, 2005.

[7] Deurenberg, P., et al. (1991). "Body mass index as a measure of body fatness: age-and sex-specific prediction formulas." British journal of nutrition 65(02): 105-114.

[8] Snehalatha, C., et al. (2003). "Cutoff values for normal anthropometric variables in Asian Indian (Folsom, Prineas et al. 1990)adults." Diabetes care 26(5): 1380-1384.

[9] M. Ramirez-Zea, B. Torun, R. Martorell, and A. D. Stein, "Anthropometric predictors of body fat as measured by hydrostatic weighing in Guatemalan adults," The American Journal of Clinical Nutrition, vol. 83, pp. 795-802, April 1, 20062006.

[10] Jackson, A. S., et al. (1979). "Generalized equations for predicting body density of women." Medicine and science in sports and exercise 12(3): 175-181.

[11] R. T. Withers, N. P. Craig, P. C. Bourdon, and K. I. Norton, "Relative body fat and anthropometric prediction of body density of male athletes," European Journal of Applied Physiology and Occupational Physiology, vol. 56, pp. 191-200, 1987/03/01 1987. 